\title{
УДК 006.015:631.526.3:635.21(477)
}

DOI: 10.30888/2663-5712.2021-07-03-050

\section{TECHNOLOGICAL INDICATORS OF COMMON VARIETIES OF MEDIUM-SIZED POTATOES}

ГОСПОДАРСЬКІ ПОКАЗНИКИ ПОШИРЕНИХ СОРТІВ СЕРЕДНЬОСТИГЛОЇ КАРТОПЛІ

\author{
Voitsekhivskyi V. / Войцехівський В. \\ PhD. / к. с.-г. н., доu. \\ Denisyuk V. / Денисюк B. \\ Student/ cтудент \\ National university of life and environmental sciences of Ukraine, Kiev
}

Slobodyanik G. / Слободяник Г.

PhD. / к. с.-2. н., дои.

National university of horticulture, Uman, Ukraine

Orlovskiy N. / Орловский Н.

PhD. / к. c.-2. H.

Polish national university, Ukraine

Vaskivska S. / Васьківська C.

Researcher / cm. H. c.

Ukrainian Institute for Plant Varieties Examination, Kiev

Muliarchuk O. / Мулярчук О.

PhD. / к. c.-2. н., доu.

State agrarian and engineering university in Podilia, Ukraine

Annotation. The results of analysis industrial evaluation of potato tubers of different varieties of middle-late ripeness are presented. It is set that sorts Promin, Aladin, Sifra, Olviya and Pikasso most valuable among investigated.

Key words: potatoes, sort, yield, chemical consist, quality.

Introduction.

Potato has a significant performance potential. Modern varieties are able to form up to 50-60 tons of commodity products from hectares. World production of commodity potatoes reaches 390 million tons. Ukraine ranks third in terms of per capita consumption of potatoes and this figure is higher than the recommended norms, so it can be argued that it is a strategic food security product. Ukraine ranks fourth in the world in the production of potato tubers, second only to China, Russia and India, and currently the needs of the population and industry are constantly growing $[1,4]$.

At the same time, to obtain high-quality raw materials, it is advisable to select highly productive samples that are resistant to diseases, pests and with high and stable chemical composition. More than 160 varieties of potato tubers of different maturity groups of domestic and foreign selection are distributed in Ukraine. However, not all varieties satisfy the producer and consumer in their characteristics. The varieties of the middle-late maturity group deserve special attention, because they have a great potential for providing the population and industry in the autumnwinter period $[2,3]$.

The aim of the research was to conduct a comprehensive economic evaluation of common and introduced varieties of potato tubers of medium-late ripeness group grown in Ukraine and to identify factors that influence the formation of these traits. 
Research methodology. The research was conducted at the department of technology of storage, processing and standardization of plant products named after prof. B.V. Lesyka of NULES of Ukraine and LLC of «Arofirm Kyivska». Evaluation of the quality of potatoes of medium late ripeness group was carried out according to the following indicators: yield, tuber weight, starch content, taste. The tubers of the following varieties were evaluated: Aladdin, Picasso, Sifra (Germany), Folva (Denmark), Uzhhorodska, Promin, Zarevo, Olvia, Rakurs and Dzvin (domestic selection). The selection of the most valuable potato samples was performed by ranking the indicators and summing the obtained conditional numbers (points) for each variety-sample. Chemical-technological analysis was performed according to generally accepted methods. Statistical data processing was performed by methods of analysis of variance and correlation $[3,4]$.

Results and discussion. We analyzed the economic indicators of potato tubers of domestic selection and introduced varieties recommended for processing into chips. The average yield of the studied varieties is $28,4 \mathrm{t} / \mathrm{ha}$. At the same time, Sifra and Aladdin had the highest yields - more than $35 \mathrm{t} / \mathrm{ha}$, and this indicator was much lower in Rakus - less than $20 \mathrm{t} /$ ha. Given the fact that the consumer focuses on the appearance when choosing products, the size of the tubers is an important characteristic of the marketability of the variety. Among the studied potato cultivars, Picasso and Promin (over $115 \mathrm{~g}$ ) had the highest average weight of tubers, and Zapevo (76 g) had the smallest. at the same time in the context of the studied varieties, this figure was $-100,5 \mathrm{~g}$ (table).

On average, according to the studied samples, the starch content was $18,3 \%$ with fluctuations in terms of varieties up to $9,6 \%$. It was found that the most starchy are the varieties of varieties - Olvia, Zapevo, Uzhgorodska and Aladdin (over 20\%). These types should be used to remove starch and alcohol, although they have a fairly high taste. The varieties with the lowest starch content include Picasso, Cipher and Folva $(16,7-15,1 \%)$. The starch content of other varieties was in the range of 15,1$23,2 \%$.

\begin{tabular}{|c|c|c|c|c|c|c|}
\hline \multicolumn{7}{|c|}{ Characteristic of varieties } \\
\hline Variety & 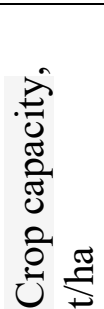 & 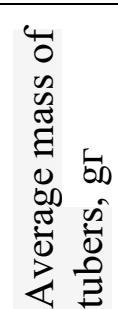 & 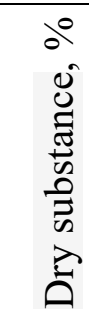 & 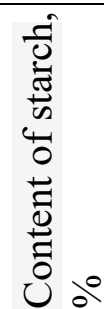 & 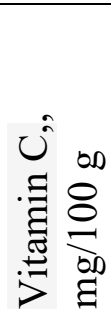 & 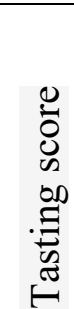 \\
\hline Aladdin & 35,0 & 105,0 & 27,5 & 20,5 & 12,4 & 8,6 \\
\hline Picasso & 31,0 & 118,0 & 20,4 & 13,7 & 8,4 & 8,1 \\
\hline Sifra & 39,5 & 119,0 & 22 & 14,8 & 11,8 & 8,1 \\
\hline Uzhhorodska & 31,4 & 101,0 & 28,3 & 20,6 & 16,5 & 7,0 \\
\hline Folva & 29,3 & 99,0 & 22,1 & 15,1 & 15,1 & 7,1 \\
\hline Promin & 32,7 & 115,0 & 23,5 & 16,3 & 22,3 & 8,5 \\
\hline Zarevo & 22,2 & 76,0 & 27,9 & 21,8 & 21,4 & 7,5 \\
\hline Olvia & 24,1 & 89,0 & 31 & 23,3 & 19,6 & 7,4 \\
\hline Rakurs & 19,0 & 98,0 & 27,5 & 20,2 & 17,8 & 8,1 \\
\hline Dzvin & 20,2 & 85,0 & 23,2 & 16,4 & 18,4 & 7,8 \\
\hline
\end{tabular}


One of the important indicators that characterizes the biological value of the product is the content of ascorbic acid. A number of scientific sources contain contradictory data on the influence of various factors on this indicator, but it is noted that favorable weather conditions, optimal fertilization, protection against pests and diseases have a positive effect on the potential of the variety, in particular the best to form higher concentrations of ascorbic acid. The content of ascorbic acid in potato tubers was on average $16,4 \mathrm{mg} / 100 \mathrm{~g}$ of raw material, and the fluctuations between varieties were $8,4-22,3 \mathrm{mg} / 100 \mathrm{~g}$. The highest content of ascorbic acid was observed in the tubers of the variety Promin $(22,3 \mathrm{mg} / 100 \mathrm{~g})$, and the lowest - Picasso and Sifra ( 8,4 and $11,8 \mathrm{mg} / 100 \mathrm{~g}$, respectively).

At present, consumers pay special attention to the culinary qualities of tubers when choosing a variety for cultivation or consumption. The formation of this indicator in turn depends on a set of factors, but primarily on varietal characteristics (chemical composition of tubers), growing conditions, application of agronomic techniques and physiological condition of tubers. For the analysis of potato tubers were boiled and analyzed by a set of organoleptic parameters. According to the study, the highest organoleptic characteristics are inherent in the tubers of varieties Aladdin, Picasso, Cipher, Ray and Foreshortening (above 8 points). Uzhhopodska and Folva potato tubers have lower indicators, 7,0 and 7,1, respectively. At the same time, the overall average score was 7,8. All analyzed varieties are suitable for consumption and production of various processing products.

It is known that the formation of the components of the chemical composition of potato tubers is interconnected, and according to the correlation calculation in the analyzed samples revealed dependences of different strength. Thus, a direct

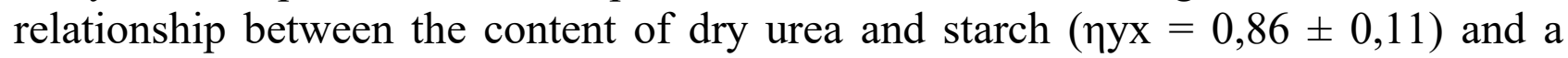
direct strong relationship between yield and average weight of potato tubers ( $0,79 \pm 0.08$ ). Of course, these dependencies can be questionable, because the yield can be high, and the average weight of tubers - low. Interesting are the inverse dependences of the average strength between yield, tuber mass and accumulation of starch and ascorbic acid $(-0,41 \ldots-0,63)$ and direct - with organoleptic characteristics $(0,29-0,50)$. Dispersion analysis of the influence of weather conditions of cultivation and variety on the studied indicators found that in most cases their formation is more influenced by varietal characteristics and less weather conditions of cultivation and the interaction of these factors.

Thus, the analysis of economic and commodity indicators showed that the highest yields and mass of tubers are: Sifra and Aladdin. At the same time, the tubers of Aladdin, Picasso, Sifra Promin and Rakurs have high taste characteristics. At the same time, a comprehensive analysis of important indicators of medium-late potato tubers is placed in the following sequence (in descending order of value): Promin, Aladdin, Sifra, Olvia, Picasso, Uzhgorodska, Zarevo, Rakurs, Dzvin and Folva.

Conclusions. Ukraine has an extremely large potential and development prospects for increasing the production and export of potato tubers. A comprehensive analysis of economic and technological indicators of potato tubers showed that they have very different properties. Comprehensive evaluation of the studied varieties of mid-late maturity group allowed to identify the most optimal varieties for 
consumption, storage and processing and the most valuable varieties are: Ray, Aladdin, Cipher, Olbia and Picasso. The analysis of variance and correlation revealed that varietal characteristics have the greatest influence on the formation of valuable economic characteristics. The obtained data should be used when planning the cultivation of competitive varieties of potato tubers. In further research, it is advisable to expand the list of varieties and the list of studied indicators and deepen research on the impact of weather conditions, cultivation techniques and fertilizers on the formation of valuable economic indicators.

\section{Literature:}

1. Кернасюк Ю. Перспективи розвитку картоплярства // Агробізнес. 2019. Реж.дост.: http://agro-business.com.ua/agro/ekonomichnyi-hektar/item/13391perspektyvy-rozvytku-kartopliarstva.html.

2. Методика дослідної справи в овочівництві і баштанництві /За ред. Г.Л. Бондаренка, К.І. Яковенка. Х.: Основа, 2001. 369 с.

3. Подпрятов Г.І. Товарознавство продукції рослинництва / Подпрятов Г.І., Скалецька Л.Ф., В.І.Войцехівський. К.: Вид-во Арістей. 2005. 256 с.

4. Теслюк П. Сорти картоплі / П. Теслюк, П. Пасічник, Ю. Вірменко, Ю. Банківська. К.: Агросвіта України, 2001. 93 с.

5. Франс Дж. Математические модели в сельском хозяйстве / Дж. Франс, Дж.Х.М. Торнли. М.: Агропромиздат, 1987. 400 с.

Анотація. Представлені результати аналізу господарської оцінки картоплі середньостиглих сортів. Встановлено, щуо сорти Промінь, Аладін, Сіфра, Ольвія та Пікассо є найбільш иінним серед досліджених.

Ключові слова: картопля, сорт, хімічний склад, якість.

Article sent: 10/03/2021

(C) Voitsekhivskyi V., Denisyuk V., Slobodyanik G., Orlovskiy N., Vaskivska S., Muliarchuk O. 